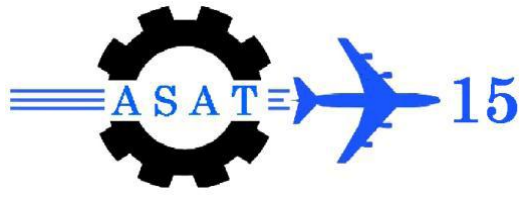

\title{
Torque Converter Operating with Power Splitting Concept
}

\author{
R.M. Abd El-Maksoud*
}

\begin{abstract}
Vast researches have been performed to enhance the torque converter due to its significance in different power transmission applications. However, some of its problems are not completely solved. Consequently, this work introduces a principal modification to the torque converter not only to eliminate such problems but also to operate it with advanced features. The present torque converter operates with the power splitting concept where its input power is split into two power paths, then combined after regulation. This system is represented by a conventional torque converter attached to one planetary gear set. Two unique positive displacement hydraulic couplings of the same type are utilized to regulate power in the two power paths. A feasible model is derived to predict and study the conventional torque converter performance where the global intrinsic losses are empirically included. Based on this model and gear kinematics, the simulated results demonstrate that the present torque converter operates as a continuously variable transmission used for different applications.
\end{abstract}

Keywords: Torque converter, power splitting, planetary gears, continuously variable transmission, vehicle.

\section{Nomenclature}

a Coefficient used in Eq. (7)

A Impeller area $\left(\mathrm{m}^{2}\right)$

b Coefficient used in Eq. (7)

C Absolute velocity $(\mathrm{m} / \mathrm{s})$

g Gravitation acceleration $\left(\mathrm{m} / \mathrm{s}^{2}\right)$

GR The gear ratio of the output gear set

$\mathrm{nr} \quad$ Number of teeth of the ring gear

ns Number of teeth of the sun gear

$\mathrm{Pm} \quad$ Mechanical power (W)

$\mathrm{Pt} \quad$ Power transferred through the conventional torque converter turbine (W)

Q Flow rate inside the torque converter $\left(\mathrm{m}^{3}\right)$

$\mathrm{r} \quad$ Radius (m)

S Slip factor

SR Seed ratio; ratio of the rotational speed of the turbine to that of the pump

$\mathrm{T}$ Torque $(\mathrm{Nm})$

TR Torque ratio; ratio of torque of the output member to that of the input

u Mean blade velocity $(\mathrm{m} / \mathrm{s})$

VR Velocity ratio; ratio of the rotational speed of the output shaft to that of the pump

W Relative velocity $(\mathrm{m} / \mathrm{s})$

Assistant professor, Faculty of Eng., Mataria, Helwan University, Cairo, Egypt; brainandspirit@yahoo.com 
$\mathrm{x} \quad$ Angular velocity of the sun gear while the arm is fixed ( $\mathrm{rad} / \mathrm{s})$

$\mathrm{y} \quad$ Angular velocity of the planetary set when all of its members are locked together $(\mathrm{rad} / \mathrm{s})$

$\mathrm{Z} \quad$ Gear ratio determined by the ratio between the angular revolution of the converter casing gear and that of the ring gear

Symbols

$\alpha \quad$ Absolute flow angle (degree)

$\beta \quad$ Blade angle (degree)

$\eta \quad$ Efficiency of the torque converter

$\eta \mathrm{m} \quad$ Mechanical efficiency

$\kappa \quad$ Ratio of power portion transferred mechanically to the input power

$\rho \quad$ Oil density $\left(\mathrm{kg} / \mathrm{m}^{3}\right)$

$\omega \quad$ Angular velocity $(\mathrm{rad} / \mathrm{s})$

\section{Subscript}

a Arm of the planetary gear set

ax Flow axial direction

o Output shaft

re Reactor

p Pump

$\mathrm{t}$ Turbine

1 Inlet

2 Exit

\section{Abbreviation}

CVT Continuously variable transmission

\section{Introduction}

Torque converter is a magnificent turbo-machine unit used for power transmissions, especially in vehicles. As it represents the main significant component in the automatic transmission, it influences vitally the transmission performance and contributes extensively in fuel consumption and emission. Therefore, several researchers [1-5] studied it to enhance its operation. However, the torque converter is limited by its operational range and suffers from many problems that are not solved, until now. Furthermore, different conventional developments applied to the torque converter are restricted due to its inherent characteristics and its integral operation with the power-train.

On the other side, the power splitting concept is a promising method used to enhance the low performance hydrostatic and hydrodynamic systems as well as systems based on power transfer through friction. This is usually accomplished by splitting the power into two portions. One of the power portions is passing through such systems while the other portion is bypassed mechanically. Thereafter, the two power portions are combined together with different output characteristic (torque and speed), [6]. Several studies have been carried out to illustrate its merits [7-12]. Vorecon is a well-known torque converter operated with such concept admitted by Voith company representing an example of a commercial application [13]. In spite of its high efficiency as a result of most of the power is transmitted mechanically, its output torque ratios are diminutive at low speeds and are not significant at higher speeds. This restricts its applications to a special power transmission field. Furthermore, this system deviates significantly from the main objective of any power 
transmission system is to have constant output power in any condition. Such desirable performance could be achieved by a typical continuously variable transmission, CVT.

The present work aims to apply the power splitting concept to the torque converter not only to enhance substantially the torque converter but also utilize it as a CVT used for vehicles, transportations and different applications. The torque converter is used to split power into two portions that are controlled by two unique couplings of the same type (vane coupling) presented in [6]. One of the two portions is transferred hydraulically while the other is transferred mechanically. A present derived model used to predict and study the conventional torque converter performance is utilized with gear kinematics to assess the current torque converter.

\section{The Power Splitting Torque Converter}

In this section, the layout and operation of present torque converter and the vane coupling used are demonstrated.

\section{Layout of the Power Splitting Torque Converter}

The global ideal of the presented concept is illustrated in Fig. 1. This layout is featured as a hydro-mechanical configuration specified by a combination of the conventional torque converter unit with a planetary gear set. The torque converter is used to split power into two portions. One of the two power portions $(\kappa)$ is transmitted mechanically via the converter casing, while the other power portion $(1-\kappa)$ is transferred hydraulically to the torque converter turbine. The two power splitting portions are controlled through two regulating units (vane couplings). The planetary gear set performs the power combination task. Consequently, the efficiency of the whole system could be improved and better using of prime mover input power with less thermal emissions could be established.

Figure 2 shows the layout of the power splitting torque converter that is composed of built-in conventional torque converter, compound type planetary gear set, ordinary gear set, two vane couples, and output gear set. The present torque converter is driven by any prime mover. The turbine and the casing of the built-in conventional torque converter are arranged to give two power outputs. On the other side, the planetary set has two power inputs that are the ring and sun gears, and one power output that is the arm. Two planetary gears are placed in-between the sun and the ring gears. The casing gear is connected to the ring gear through an ordinary gear set forming a reaction member of the system. Vane coupling is placed in this set to regulate the torque and thus the power portion of this power path. The turbine shaft is attached to the sun gear shaft by another vane coupling that controls the power portion that transferred to the turbine.

The configuration of the planetary set extends the rotational speed range of the output member more than that of the turbine. The arm rotates in both forward and reversed directions according to the velocity of the sun and ring gears. For higher rotational speeds of the turbine, the arm rotates in the reverse direction relative to that of the input shaft. In this case, the builtin conventional torque converter operates in its high-performance zone. Consequently, the output gear set is utilized to rotate the output shaft in the direction of the input shaft to achieve better operation in the forward direction. In order to recognize the operation of the present torque converter, layout and operation of the vane coupling are initially described. 


\section{Layout and Operation of the Vane Coupling}

Vane coupling introduced in this work is typically presented in the finding of [6] where it is specified as compact positive displacement hydraulic coupling. Such coupling is utilized in the power splitting torque converter to regulate torque and thus power in the power paths. This coupling, Fig. 3, is similar, to a certain extent, to the axisymmetric vane pump that is composed mainly of rotor, vanes, casing. The main distinct feature is that the casing of the coupling is not fixed and is connected to another shaft. The oil ports are either used to supply oil to the chambers confined by the sliding vanes, the casing, and the rotor, or discharge oil out of them. Discharging oil is performed to control the relative spinning between the rotor and casing. Preventing oil from discharge from the oil ports results in the spinning of the rotor and the casing together. In this case, the coupling operates in the locking mode. On the other side, allowing oil from discharging makes a slippage between the rotor and the casing, and the coupling is operating in its unlocking mode.

The torque capacity transferred by the vane coupling is determined by the oil pressure inside the coupling. Changing the oil pressure inside the coupling is accomplished by an electronic hydraulic system. This alters the torque capacity and results in transmitting a particular torque according to the build-up pressure. If there is no build-up pressure, the vane coupling is idled or fully unlocked. During torque transmission, the build-up pressure is increased leading the casing to transfer torque. When the coupling operates in the locking mode, the coupling casing and the rotor will spin together according to the transmitted torque. For less torque transmission demand, the build-up pressure inside the coupling is reduced. This causes the casing to spin slower than the rotor. Thereafter, the required transmitted torque is established causing no relative motion between the rotor and the casing.

\section{Power Splitting Torque Converter Operation}

The operation of the power splitting torque converter is based on controlling the power portions passing through the power paths. When the torque converter is idling, the two vane couplings are fully unlocked. To start power transference for certain turbine rotational velocity, the two couplings operate instantly in the unlocking mode. Control the power portions in the power paths is accomplished by reducing the build-up pressure in one of the two vane couplings (non-locking mode) while increasing or keeping constant that inside the other (locking mode). This may take a few tens of relative revolutions between the rotor and the casing of the coupling. Consequently, one of the couplings will be capable of handling more torque if the torque in the other path is decreased. Thereafter, the two vane couplings are both locked. Different build-up pressures in the two couplings are attained to transmit definite torque in each power path and control the output power characteristic. To rotate the output shaft in the direction of the input shaft, the turbine operates at a certain rotational speed range. Below this rotational speed range, the output shaft speed is reversed. On the other side, another type of control strategy is performed when the two couplings operate all the time in the locking mode while changing of the turbine speed.

\section{Modeling and Gear Kinematics}

Since the power splitting torque converter is mainly composed of; a built-in conventional torque converter connected to planetary gear. Accordingly, to analyze the present system, there is a need to predict the performance of the conventional torque converter while considering the gear kinematics. 


\section{Modeling of the Conventional Torque Converter}

Based on the findings of [1], the torque exerted on the fluid by the pump (Tp) is:

$$
\mathrm{T}_{\mathrm{p}}=\rho \mathrm{Q}\left(\omega_{\mathrm{p}} \mathrm{r}_{\mathrm{p} 2}^{2}+\left(\cot \beta_{\mathrm{p} 2} \mathrm{r}_{\mathrm{p} 2} / \mathrm{A}_{\mathrm{p} 2}-\cot \beta_{\mathrm{re} 2} \mathrm{r}_{\mathrm{re} 2} / \mathrm{A}_{\mathrm{re} 2}\right) \mathrm{Q}\right) / \mathrm{g}
$$

where $\mathrm{A}$ is the impeller area, $\mathrm{g}$ is the gravitational acceleration, $\mathrm{Q}$ is the flow rate, $\mathrm{r}$ is the pump outer radius, $\beta$ is the blade angle, $\rho$ is the fluid density, $\omega$ is the angular velocity. The subscripts $\mathrm{p}$ and re denote the pump and reactor conditions, respectively. The subscript 2 denotes the outlet condition. The above equation represents the ideal limited engine torque given to the pump. The driving torque exerted by the fluid in the turbine rotor $(\mathrm{Tt})$ could be expressed as:

$$
\mathrm{T}_{\mathrm{t}}=\rho \mathrm{Q}\left(\omega_{\mathrm{p} 2} \mathrm{r}_{\mathrm{p} 2}^{2}+\left(\cot \beta_{\mathrm{p} 2} \mathrm{r}_{\mathrm{p} 2} / \mathrm{A}_{\mathrm{p} 2}-\cot \beta_{\mathrm{t} 2} \mathrm{r}_{\mathrm{t} 2} / \mathrm{A}_{\mathrm{t} 2}\right) \mathrm{Q}-\mathrm{r}_{\mathrm{t} 2}^{2} \omega_{\mathrm{t} 2}\right) / \mathrm{g}
$$

where the subscript $t$ denotes the turbine. Therefore, the torque ratio (TR) can be written as:

$\mathrm{TR}=\mathrm{T}_{\mathrm{t}} / \mathrm{T}_{\mathrm{p}}$

Referring to Fig. 4, the author assumed that the absolute flow angle at the pump exit ( $\alpha$ p2) equals the inlet blade angle of the turbine $(\beta \mathrm{t} 1)$ at turbine stalling $(\mathrm{SR}=0)$. Consequently, the absolute velocity of the flow leaving the pump $(\mathrm{Cp} 2)$ and the relative velocity entering the turbine (wt1) are equal. For SR has a value other than zero, the peripheral velocity of the turbine equals to SR xup2 (up2 is the mean blade velocity at the outlet of the pump impeller). In this situation, the flow enters the turbine with $\beta \mathrm{t} 1$ differs than $\alpha \mathrm{p} 2$. It is assumed that the axial flow velocity leaving the pump (Cpax2) equals to that entering the turbine (Ctax 1$)$. This assumption is accepted as the gap between the turbine and pump is small.

From this figure, the axial velocity is expressed as:

$$
\mathrm{C}_{\mathrm{pax} 2}=\mathrm{C}_{\mathrm{p} 2} \sin \left(\beta_{\mathrm{p} 2}\right)
$$

The absolute flow velocity at the pump exit is given by:

$$
\mathrm{C}_{\mathrm{p} 2}=\mathrm{u}_{\mathrm{p} 2}(1-\mathrm{SR}) /\left(\sin \left(\beta_{\mathrm{p} 2}\right) \cot \left(\beta_{\mathrm{p} 2}\right)+\cos \left(\beta_{\mathrm{p} 2}\right)\right)
$$

The flow rate is determined by:

$\mathrm{Q}=\mathrm{SC}_{\mathrm{p} 2} \mathrm{~A}_{\mathrm{p} 2}$

where $\mathrm{S}$ is a correction factor that considers empirically the global intrinsic losses. Since the conventional torque converter unit operates with different SR, this leads to the sensible variation of such losses over the operating range. Therefore, the correction factor proposed herein can be written as:

$\mathrm{S}=\mathrm{aSR}+\mathrm{b}$

where and $a$ and $b$ are two imperial coefficients, and SR is the ratio of the rotational speed of the turbine to that of the pump. The efficiency of the conventional torque converter is determined by the following equation: 
$\eta=\mathrm{TR} \times \mathrm{SR}$

\section{Gear Kinematics}

In order to determine the gear kinematics, it is essential to specify the gear kinetics and the torque exerted on the gears. The power portions in the two power passes are determined by the following relations:

$$
\mathrm{P}_{\mathrm{m}}=\kappa \mathrm{T}_{\mathrm{p}} \omega_{\mathrm{p}} \text { and } \mathrm{P}_{\mathrm{t}}=(1-\kappa) \mathrm{T}_{\mathrm{t}} \omega_{\mathrm{t}}
$$

where $\mathrm{Pm}$ is the mechanical power, and $\mathrm{Pt}$ is the power transferred through the conventional torque converter turbine. To derive the TR and VR of the present torque converter, the angular velocities of all the gear train elements should be specified. Consequently, the planetary kinetics are determined by Table 1 . The parameter $\mathrm{x}$ and $\mathrm{y}$ are defined as the angular velocity of; the sun gear when the arm is locked, and the whole planetary set when it is locked, respectively.

Table 1. Planetary gear kinetics.

\begin{tabular}{c|c|c|c}
\cline { 2 - 4 } Arm locked & Sun gear & Arm & Ring gear \\
\hline System locked & $\mathrm{x}$ & 0 & $\frac{\mathrm{n}_{\mathrm{s}}}{\mathrm{n}_{\mathrm{r}}}$ \\
\hline Resultant & $\mathrm{y}+\mathrm{y}$ & $\mathrm{y}$ & $\left(\frac{\mathrm{n}_{\mathrm{s}}}{\mathrm{n}_{\mathrm{r}}} \mathrm{x}+\mathrm{y}\right)$ \\
\hline \hline
\end{tabular}

The torque of the arm (Ta) is given by:

$\mathrm{T}_{\mathrm{a}}=\eta_{\mathrm{m}}\left((1-\kappa)(\mathrm{x}+\mathrm{y}) \mathrm{T}_{\mathrm{t}} \omega_{\mathrm{t}} \eta_{\mathrm{t}}+\kappa\left(\mathrm{n}_{\mathrm{s}} \mathrm{x} / \mathrm{n}_{\mathrm{r}}+\mathrm{y}\right) \mathrm{T}_{\mathrm{p}} \omega_{\mathrm{p}} \mathrm{z}\right) / \mathrm{y}$

where $\mathrm{nr}$ is the number of teeth of the ring gear, $\mathrm{ns}$ is the number of teeth of the sun gear, $\mathrm{Z}$ is the gear ratio determined by the ratio between the angular revolution of the converter casing gear and that of the ring gear, and $\eta m$ is the mechanical efficiency. In the above equation, the losses of the vane couplings are not considered, since they appear negligibly when operating in the unlocking mode. For the output ordinary gear set, the output torque is expressed as:

$\mathrm{T}_{\mathrm{o}}=\mathrm{T}_{\mathrm{a}} \mathrm{y} / \omega_{\mathrm{o}}$

where the subscript o denotes the output shaft. The efficiency $(\eta)$, TR and VR of the power splitting torque converter could be written as:

$\eta=\mathrm{T}_{\mathrm{o}} \omega_{\mathrm{o}} /\left(\mathrm{T}_{\mathrm{p}} \omega_{\mathrm{p}}\right) \quad, \quad \mathrm{TR}=\mathrm{T}_{\mathrm{a}} \mathrm{GR} / \mathrm{T}_{\mathrm{p}}, \quad \mathrm{VR}=\mathrm{y} /\left(\omega_{\mathrm{p}} \mathrm{GR}\right)$

where GR is the gear ratio of the output gear set, and VR is the ratio of the rotational speed of the output shaft to that of the pump. 


\section{Simulations}

Simulations are performed to illustrate the feasibility of the present model, the conventional torque converter constraints, and the merits of the current torque converter. Primarily, the model feasibility is done using the performance characteristic of the traditional converter presented in [2] where its dimensional specifications are given in Table 2. Then, the model simulated results give a demonstrative example of operational restrictions and modification limits of this conventional converter. Such converter represents the built-in converter used in the present split power torque converter. Finally, comparisons between the two converters are performed to show the principal modification merits. Moreover, ideal CVT is also included in comparison to exemplify some features of the present system. Such CVT is featured with $100 \%$ efficiency where its performance is determined by Eq. (12). The values of $a$ and $b$ used in Eq. (7) are equal to 0.24 and 0.435 . The number of teeth of the sun and ring gears is 40 and 60. The values of Z, GR and $\eta \mathrm{m}$ are 4:1, 1:1 and 0.96. All the simulations are performed at input shaft speed of $1600 \mathrm{rpm}$.

Table 2. Torque converter dimensions used in [2].

\begin{tabular}{|c|c|c|c|c|c|c|}
\hline & \multicolumn{2}{|c|}{ Pump } & \multicolumn{2}{|c|}{ Turbine } & \multicolumn{2}{|c|}{ Reactor } \\
\hline & Entrance & Exit & Entrance & exit & Entrance & exit \\
\hline Number of vanes & \multicolumn{2}{|c|}{22} & \multicolumn{2}{|c|}{24} & \multicolumn{2}{|c|}{20} \\
\hline Wheel radius (mm) & 138.9 & 199.9 & 202.2 & 138.9 & 129.9 & 129.9 \\
\hline Width of flow path (mm) & 36.5 & 26.5 & 25.7 & 36.5 & 40 & 40 \\
\hline $\begin{array}{l}\text { Thickness of the vanes } \\
(\mathrm{mm})\end{array}$ & 3 & 3.7 & 4 & 2 & 5.4 & 2.5 \\
\hline Angle of vanes $\left(^{\circ}\right)$ & 129 & 95 & 36 & 155 & 124 & 27 \\
\hline $\begin{array}{l}\text { Spread length of vanes } \\
(\mathrm{mm})\end{array}$ & \multicolumn{2}{|c|}{87.5} & \multicolumn{2}{|c|}{132.5} & \multicolumn{2}{|c|}{86.5} \\
\hline
\end{tabular}

Figure 5 demonstrates a comparison between the simulated results of the model, and the experimental results of the conventional torque converter introduced by [2]. Feasibility of the equations is illustrated with good matching between the two results. Consequently, the present model could be used to predict and study the performance of the conventional torque converter.

Figure 6 shows the effect of the exit reactor blade angle ( $\beta$ re2) on the torque ratio and the efficiency of the conventional torque converter. The TR ratio in the low SR zone is noticeably enhanced with the decrease of $\beta$ re 2 values. Such effect is diminutive with the further increase of SR where raising TR in the higher range of SR is an important issue. On the other hand, the reduction of $\beta r e 2$ increases the efficiency and shifts its peak values towards lower SR. This is not preferable since there is still restricted operating range, and the shifting gaps in the transmission used such modified converter may be increased. Consequently, modifications done to the conventional torque converter are sometimes confined when reaching certain enhancement level.

Figure 7 describes the variation of VR of the present torque converter with SR of its built-in conventional torque converter. The present torque converter covers a larger operating range than the conventional converter in both forward and reversed directions denoted by the positive and negative VR values. This range in both directions depends solely on the gear ratios of the planetary gear set, and that of the ordinary gears attached to it.

Figures 8 and 9 demonstrate a comparison between the present and the conventional torque 
converter. The operation of the traditional torque converter is inefficient, especially at low SR. Moreover, such operation that is characterized by a single characteristic line is restricted to a certain operating range. On the other side, the present torque converter solves these problems and makes no significant need to modify the torque converter internal components for operation enhancement. Variation of $\kappa$ achieves output power operational band with enhanced performance in a large range of forward and reverse directions. However, operation in very small VR values that represents the starting condition is achieved by operating the vane coupling instantly in the unlocking mode. Such operation is determined by dotted lines that connect the efficiency curves, Fig. 9.

For convenience, Fig. 10 demonstrates the characteristics of the conventional torque converter, the present system and the ideal CVT. As it is clearly seen that there is a significant deviation between the characteristic of the conventional torque converter and that of CVT, especially at low SR. On the other side, the present system characteristic curve approaches the ideal curve with the increase of $\kappa$. According to these presented results, the current torque converter could be classified as a new class of a CVT with few simple components. Such transmission class could be used in vehicles, transportations and different applications.

\section{Conclusions}

From this work, the following conclusions are drawn:

The present torque converter is introduced to form a new class of continuously variable transmission with fewer components for different power transmission applications.

Vane coupling characterized with compact features is used to regulate power portions in power paths.

A validated model is presented to predict the conventional torque converter performance. This model considers empirically the global intrinsic losses, and it is used with the planetary set kinematics to assess the present torque converter.

Modifications done to the internal components of the conventional torque converter are sometimes confined when reaching certain enhancement level.

There is no significant need to modify the internal components of the conventional torque converter in order to enhance its operation when operating with the power splitting concept.

\section{References}

[1] Eksergian, R., "The fluid torque converter and coupling", J. of The Franklin Inst., 1943, vol. 235, pp. 410-478.

[2] Kaihua, Y., Qingdong, Y., and Muqiao Z., "Computational aided calculation of hydraulic torque converter original characteristic", Proc. of the Fifth International Conference on Fluid Power Transmission and Control, 2001, vol. 4, pp. 533-536.

[3] Dong, Y., Korivi, V., Attibele, P., and Yuan Y., "Torque converter CFD engineering Part I: Torque ratio and $\mathrm{K}$ factor improvement through stator modifications", Transmission and Driveline Systems Symposium, (SP-1655), SAE, World Congress Detroit, Michigan March, 2002, pp. 4-7. 
[4] Wei, W., and Qingdong, Y., "Study on hydrodynamic torque converter parameter integrated optimization design system based on tri-dimensional flow field theory", SAE Int. Powertrains, Fuels and Lubricants Congress, Shanghai, China June, 2008, pp. 23-25.

[5] Kim, M., Song, K., Kim, K., Park, J., Kook, J., Oh, J., and Cho, J., "Development of the integrated process for torque converter design and analysis", World Congress, Detroit, Michigan April, 2008, pp. 14-17.

[6] Abd El-Maksoud, R.M., "Controlled power splitting and combining transmission (CPSCT)", World Intellectual Property Organization, WO 00/71905, 2000.

[7] Lu, Z., "Acceleration simulation of a vehicle with a continuously variable power split transmission", MSc thesis, College of Engineering and Mineral Resources, West Virginia University, 1998.

[8] Shellenberger, M.J.C., "Design considerations for variable power split hydraulic drives for industrial applications", MSc thesis, College of Engineering and Mineral Resources, West Virginia University, 1999.

[9] Setlur, P., Wagner, J.R., Dawson, D.M., and Samuels B., "Nonlinear control of a continuously variable transmission (CVT)", Control Systems Technology, IEEE Trans., 2003, vol. 11, pp. 101-108.

[10] Fox, A.J., "Design and analysis of a modified power split continuously variable transmission", $\mathrm{PhD}$ thesis, College of Engineering and Mineral Resources, West Virginia University, 2003.

[11] Gomez, M.M., "A Continuously variable power-split transmission in a hybrid-electric sport utility vehicle", MSc thesis, College of Engineering and Mineral Resources, West Virginia University, Morgantown, West Virginia, 2003.

[12] Miller, J.M., "Hybrid electric vehicle propulsion system architectures of the e-CVT type", Power Electronics, IEEE Trans., 2006, vol. 21, pp. 756-767.

[13] http://www.voithturbo.com/applications/vtpublications/downloads/214_e_cr168_en_vorecon-variable-speed-planetary-gear.pdf 


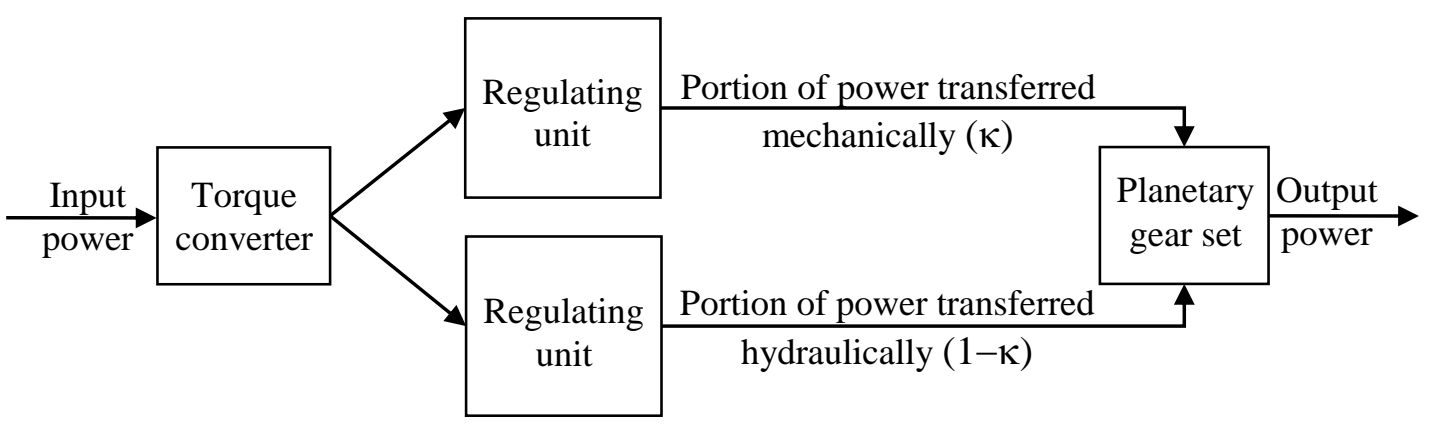

Fig. 1 General arrangement of the power splitting torque converter.

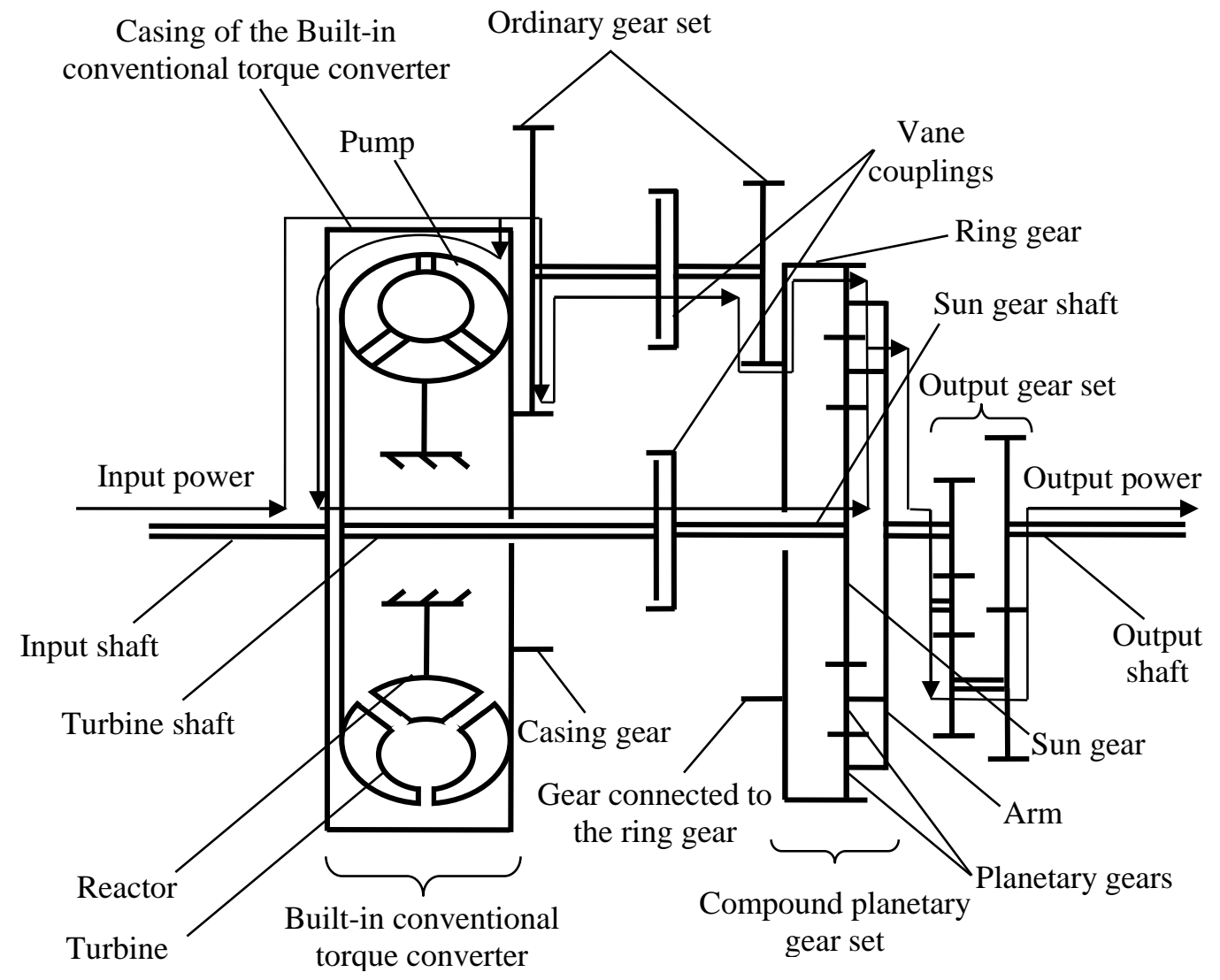

Fig. 2 Power splitting torque converter components. 


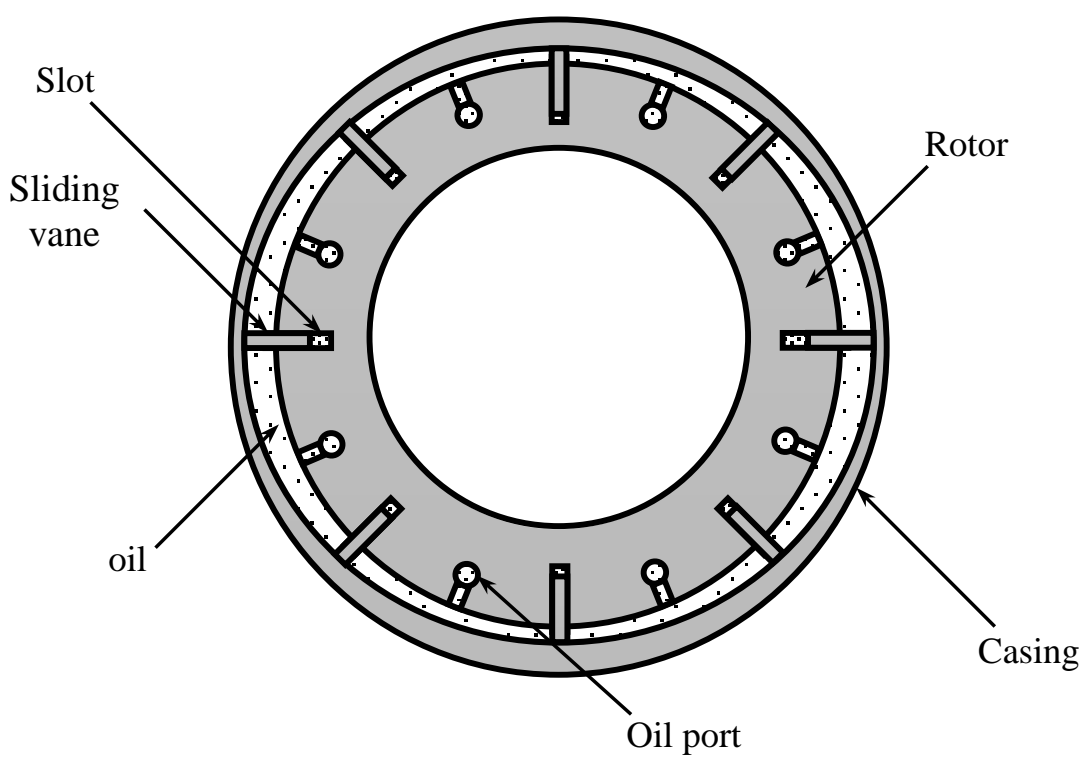

Fig. 3 Vane coupling construction, [6].
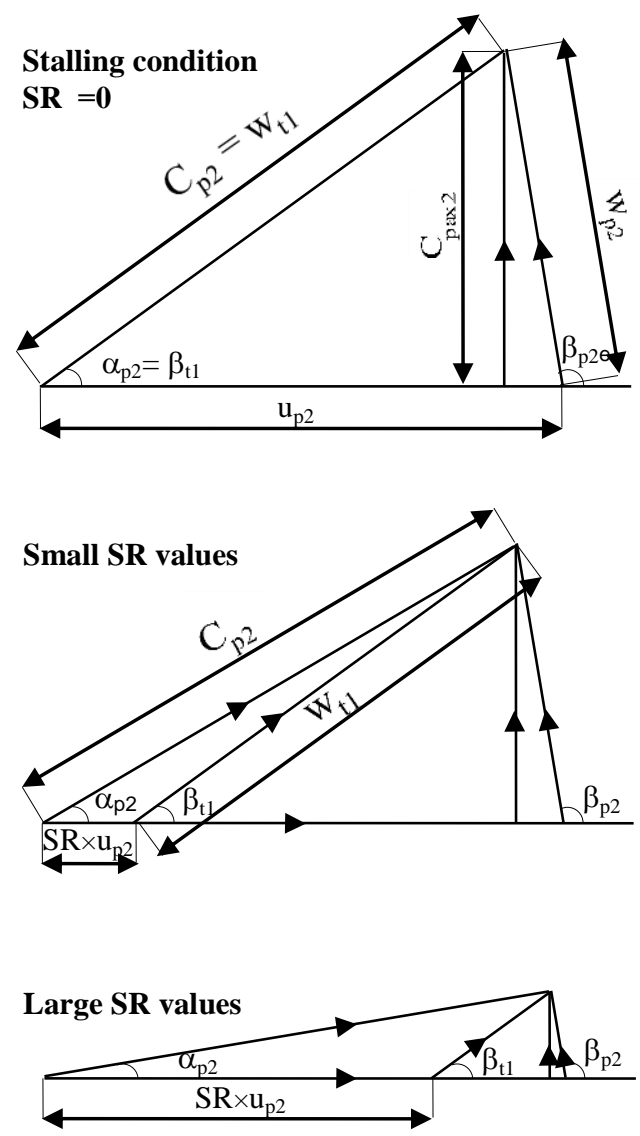

Fig. 4 Velocity triangles at the pump exit and turbine entry. 


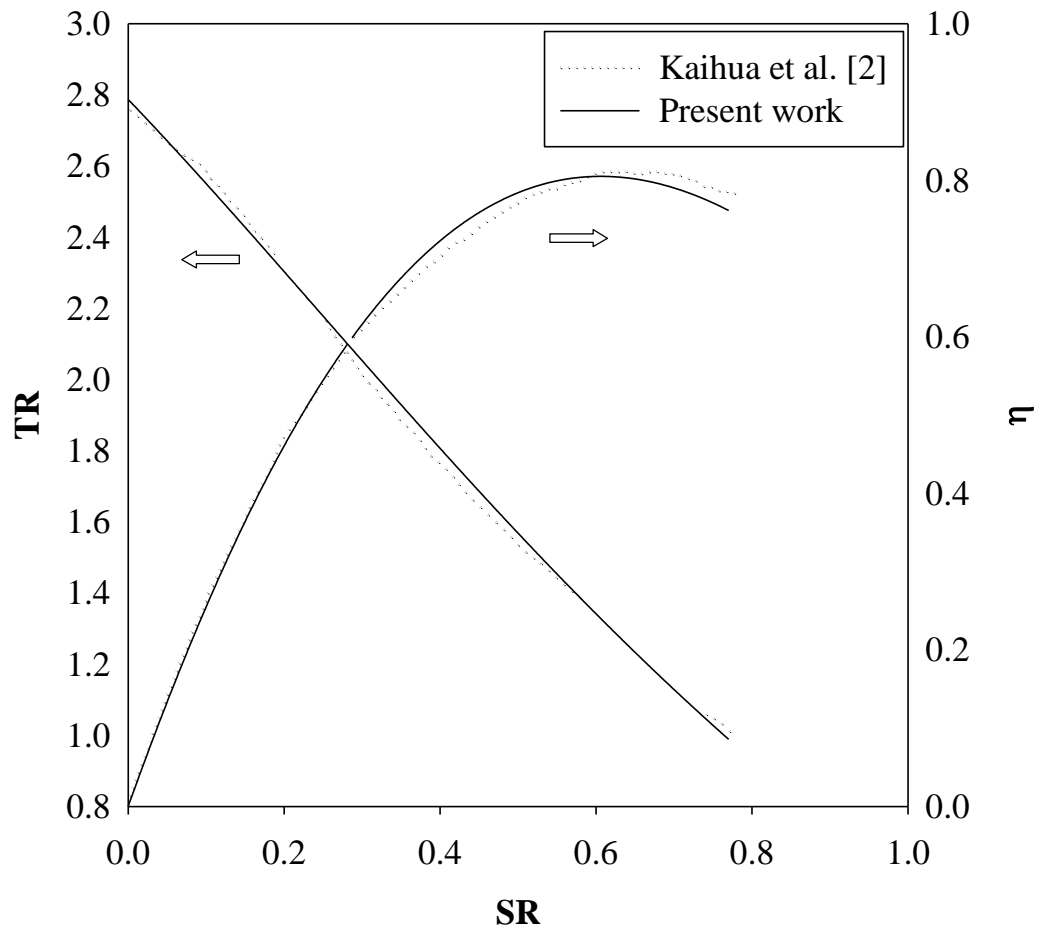

Fig. 5 Comparison between the present model and the experimental results of the conventional torque converter introduced by [2].

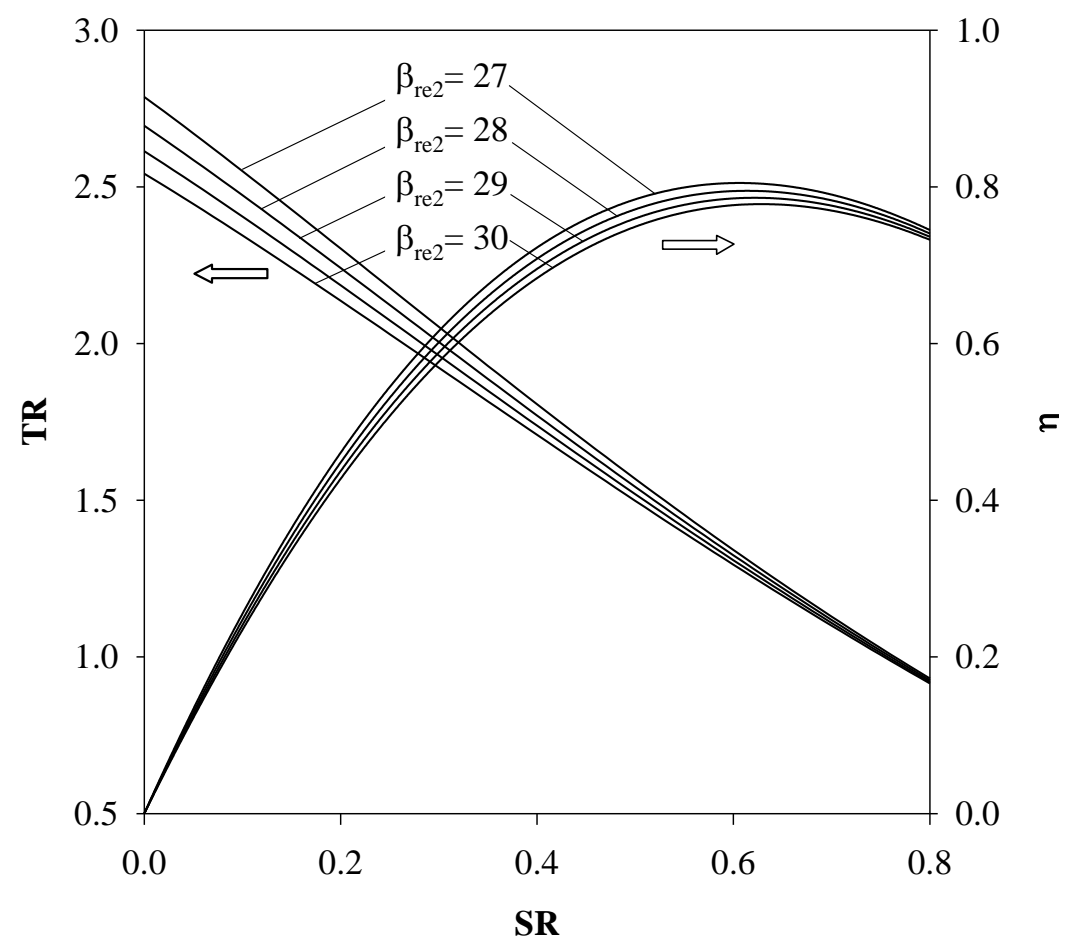

Fig. 6 Effect of exit reactor blade angle on TR and $\eta$ of the conventional torque converter. 


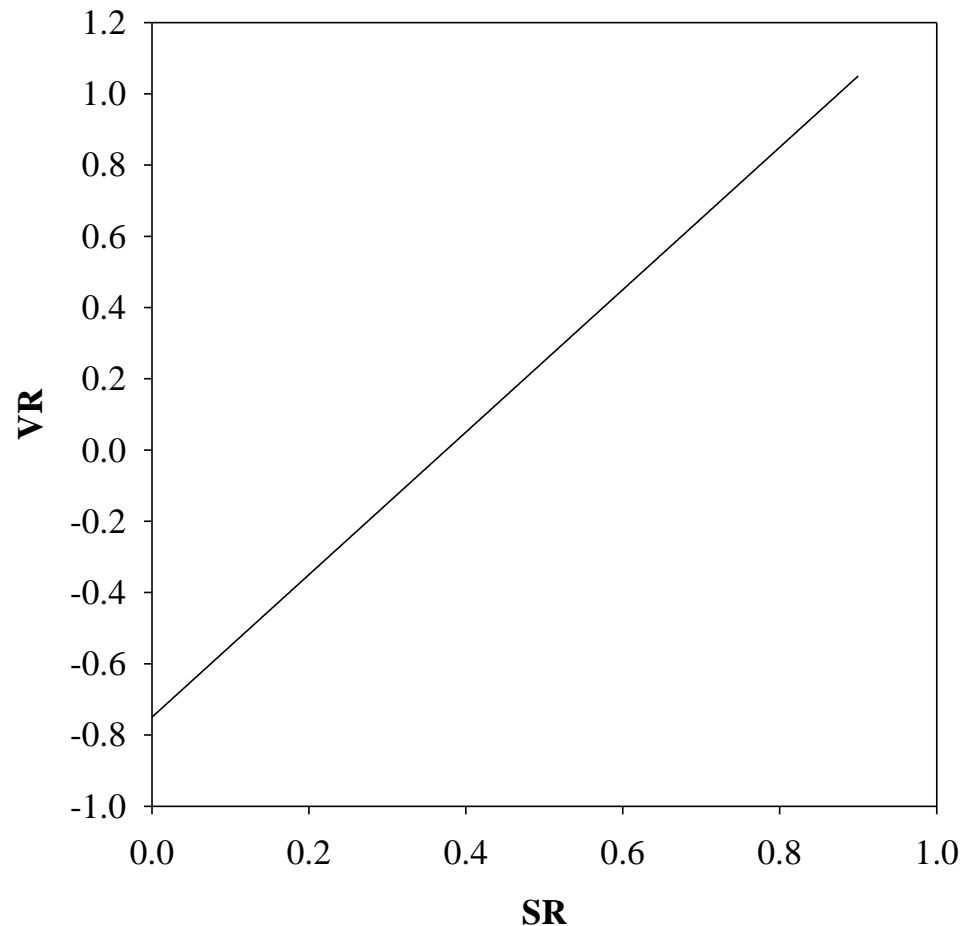

Fig. 7 Variation of VR with SR.

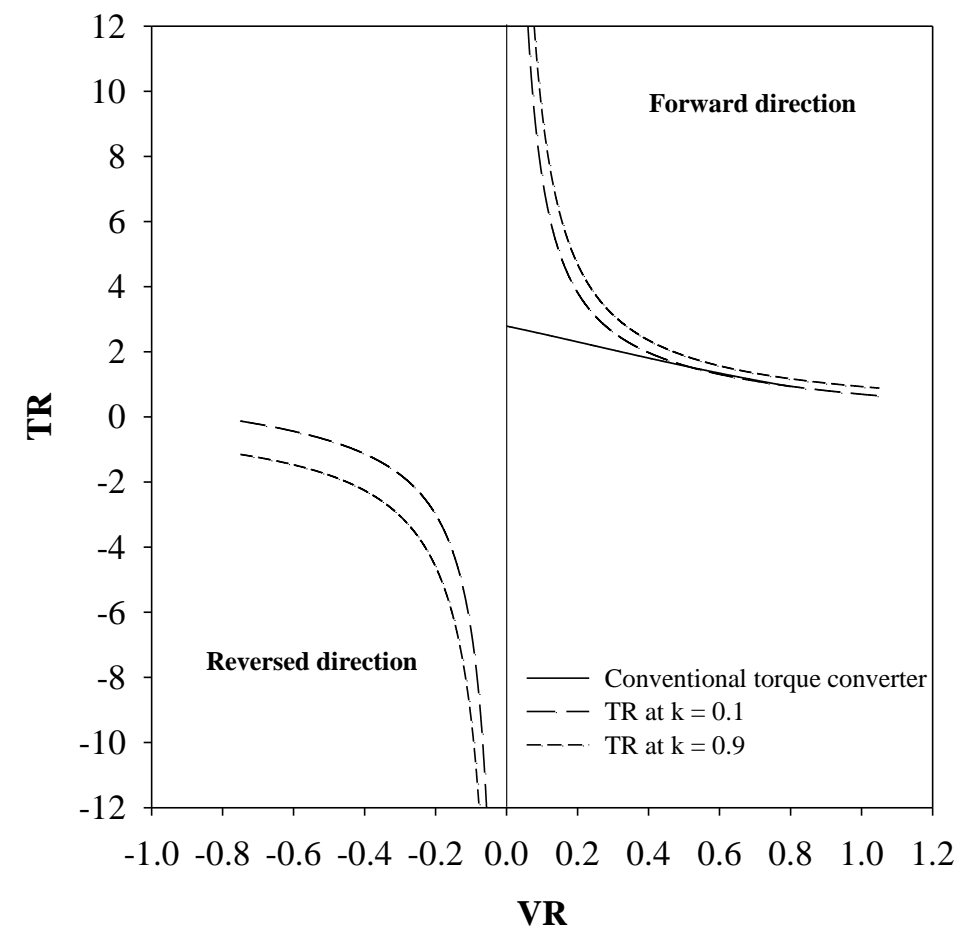

Fig. 8 Comparison between power splitting torque converter and conventional torque converter on the basis of $\mathbf{T R}$. 


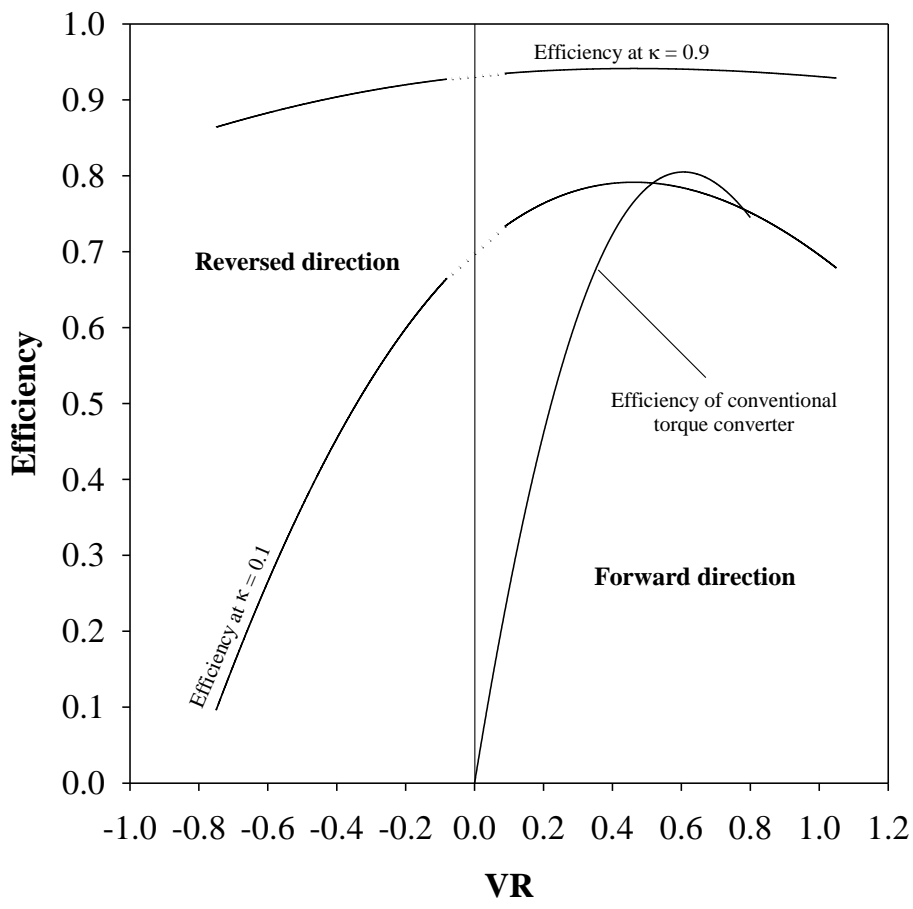

Fig. 9 Comparison between power splitting torque converter and conventional torque converter on the basis of the efficiency.

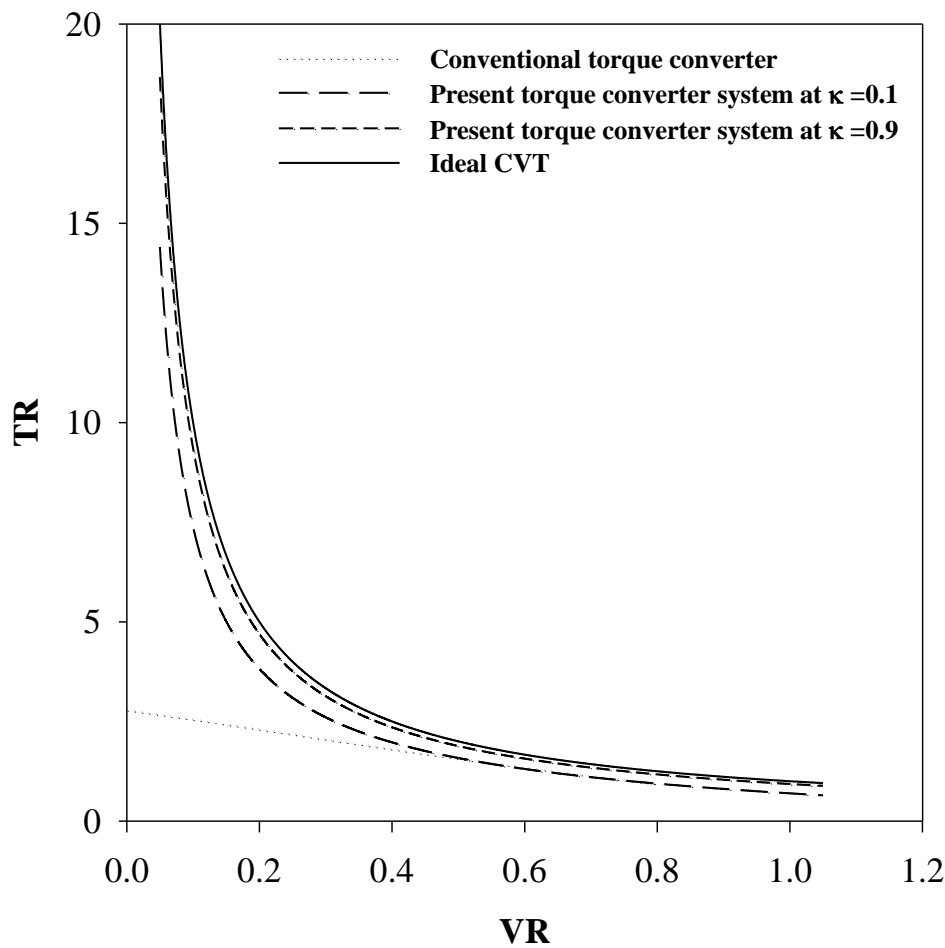

Fig. 10 Comparison between the conventional torque converter, the present torque converter system and the ideal CVT. 